\title{
Estrus induction and fertility response in delayed pubertal Kankrej heifers treated with norgestomet ear implant
}

\author{
C. F. Chaudhari ${ }^{1}$, B. N. Suthar ${ }^{2}$, V. K. Sharma ${ }^{2}$, V. S. Dabas ${ }^{3}$, N. F. Chaudhari ${ }^{4}$, H. H. Panchasara ${ }^{5}$ \\ 1. Dept. of ARGO, College of Veterinary Science and AH, Navsari Agricultural University, Navsari 396450 , \\ India; 2. Dept. of ARGO, College of Veterinary Science and AH, SardarKrushinagar Dantiwada Agricultural \\ University, SK Nagar - 385 506, India; 3. TVCC, College of Veterinary Science and AH, NAU, Navsari ; \\ 4. Dept. of ARGO, College of Veterinary Science and AH, NAU, Navsari 396450 ; \\ 5. Livestock Research Station, SDAU, SK Nagar - 385506 \\ Corresponding author: C. F. Chaudhari, email:drcfchaudhari@yahoo.co.in \\ Received: 22-01-2012, Accepted: 10-02-2012, Published Online: 24-05-2012 \\ doi: $10.5455 /$ vetworld.2012.453-458
}

\begin{abstract}
Aim: The study was undertaken to find out the estrus induction and fertility response in delayed pubertal Kankrej heifers treated with norgestomet ear implant.

Materials and methods: Total eighteen anoestrus Kankrej heifers of delayed puberty weighed above $250 \mathrm{~kg}$ and attained between 30 to 36 months of age were selected and divided in to three groups of six animals each at random to conduct the experiment. Animals in group 1 were implanted Crestar ear implant for 9 days. In addition to this, group 2 received 500 IU of PMSG on the day of implant removal. In group 3, treatment protocol remained same as in group 2, but Inj. Receptal @ 2 ml was given additionally at the time of breeding.

Results: All the animals exhibited estrus with average duration of $25.41 \pm 0.94,21.95 \pm 0.20$ and $22.68 \pm 1.46$ hours between implant withdrawal and estrus induction in group 1, 2 and 3 , respectively. The duration of estrus was significantly (P<0.05) longer $(25.61 \pm 2.95$ hours) in group 2 , followed by group 1 (18.88 \pm 1.45 hours) and group 3 (13.48 \pm 1.92 hours). The pregnancy rate at induced estrus was 33.33 percent in group 2. In group 1 and group 3 none of the heifers found pregnant at induced estrus. The overall conception rate was maximum in group 2 (66.67 percent) followed by group 3 (50 percent) and group 1 (33.33 percent) after the $3^{\text {rd }}$ service.

Conclusion: Although the conception rate at induced estrus was lower, norgestomet ear implant could be utilized to induced estrus in delayed pubertal cow heifers.

Key words: Conception rate, Delayed puberty, Estrus induction, Heifers, Norgestomet

To cite this article: Chaudhari CF, Suthar BN, Sharma VK, Dabas VS, Chaudhari NF, Panchasara HH (2012) Estrus induction and fertility response in delayed pubertal Kankrej heifers treated with norgestomet ear implant, Vet World, 5(8): 453-458. doi: 10.5455/vetworld.2012.453-458
\end{abstract}

\section{Introduction}

Puberty in the female is defined as the attainment of a developmental state that supports normal ovarian cyclicity (follicular development and ovulation) and the ability to become pregnant. The event is of prime importance among the post - natal phenomenon of reproductive origin. High life time reproductive efficiency requires early attainment of puberty. Delayed puberty is considered to be the most important challenging problem associated with dairy heifer reproduction particularly in countries like India. It is the main cause of lowered fertility in heifers and is responsible for huge economic losses to the dairy farmers by decreasing life time milk yield and the number of calves produced by a cow in her lifetime. Inspite of having attained pubertal age and body weight, a large percentage of Indian zebu heifers fail to commence cyclicity [1].
Delayed onset of puberty lowers the reproductive rate of females as it delays their entry into breeding herds [2]. This necessitates exogenous intervention to induce ovarian activity in delayed pubertal animals. In addition to herbal heat inducer drugs [3-7] biostimulation [8,9] vitamin and mineral mixture supplementation [10,11] several hormonal preparations also available to induce estrus [12-16] in cyclic as well as acyclic animals. Hormonal preparations for induction of estrus include administration of prostaglandin, progesterone, gonadotrophins and Gonadotrophin Releasing Hormone (GnRH) or their synthetic analogues, either alone or in various comb-inations. Progesterone treatment successfully induces ovarian cyclicity in bovines $[12,15,17,18,19]$. Equine Chorionic Gonadotrophin (eCG) has been frequently used with progesterone to induce fertile estrus and also to stimulate final follicular maturation and ovulation 
Estrus induction and fertility response in delayed pubertal Kankrej heifers treated with norgestomet ear implant

Table - 1. Estrus induction response in different groups of Kankrej heifers treated with Crestar ear implant

\begin{tabular}{lccc}
\hline Parameter & Group 1 (NOR) & Group 2 (NOR + PMSG) & Group 3 (NOR + PMSG + GnRH) \\
\hline $\begin{array}{l}\text { Number of heifer treated } \\
\begin{array}{l}\text { Induction of estrus } \\
\text { (Heifers responded) }\end{array}\end{array}$ & $\mathrm{n}=6$ & $\mathrm{n}=6$ & $\mathrm{n}=6$ \\
$\begin{array}{l}\text { Onset of estrus after withdrawal } \\
\text { of implant (hr), Mean } \pm \text { SEM }\end{array}$ & $25.41 \pm 0.94$ & $6(100)$ & $60)$ \\
$\begin{array}{l}\text { Duration of estrus (hr), } \\
\text { Mean } \pm \text { SEM }\end{array}$ & $18.88^{\mathrm{ab}} \pm 1.45$ & $21.95 \pm 0.20$ & $22.68 \pm 1.46$ \\
\hline
\end{tabular}

a, b: Means bearing different superscript within row differ significantly $(P<0.05)$, Figures in parenthesis indicate percentage.

in anoestrus cattle [1]. Crestar implant alone and in combination with Folligon was tried by Nayak et al. [20] for estrus induction in true anoestrus buffaloes. Since GnRH has the property of inducing follicular growth and ovulation, incorporation of GnRH in the norgestomet regimen may improve fertility in anoestrus cows [21]. The mechanism of action of both human Chorionic Gonadotrophin (hCG) and GnRH is via the induction of accessory corpus luteum (CL) by ovulating the dominant follicle of the first follicular wave as well as having a stimulatory effect on the production of progesterone by the primary CL[22]. Keeping all these facts in view, the present study was undertaken on delayed pubertal Kankrej heifers to evaluate the efficacy of Crestar ear implant alone or in combination with PMSG and GnRH in inducing estrus and subsequent fertility response.

\section{Materials and Methods}

Animals: The study was approved by the committee framed for the research by the university authority. The present investigation was carried out during the period from December 2003 to June 2004 on anoestrus Kankrej heifers of delayed puberty weighed more than $250 \mathrm{~kg}$ body weight and attained over 30 months of age, because at least at this stage of age and body weight the heifers should reach their puberty. Such 18 heifers of Livestock Research Station, Sardarkrushinagar Dantiwada Agricultural University, Sardarkrushinagar were selected and randomly divided in to three groups i.e., group 1 (NOR); group 2 (NOR + PMSG) and group $3(\mathrm{NOR}+\mathrm{PMSG}+\mathrm{GnRH})$. Each group included 6 heifers. All the experimental animals were maintained under uniform managemental conditions.

Treatment Protocols: Animals of all the three groups were treated with $3 \mathrm{mg}$ norgestomet ear implant (Crestar®; Intervet International B.V.-Boxmeer, Holland) subcutaneously in the middle of the outer face of the ear pinnae with the help of special applicator. At the time of implant insertion $2 \mathrm{ml}$ Crestar injection (3 $\mathrm{mg}$ norgestomet and $5 \mathrm{mg}$ oestradiol valerate) was administered intramuscularly.
The implants were kept in situ for the period of 9 days. In the NOR group, no drug was administered at the implant removal. In NOR + PMSG group, 500 IU Folligon (Intervet International B.V.-Boxmeer, Holland) injected intramuscularly on day 9 immediately after implant removal. In addition to the treatment regimen of NOR + PMSG group, the heifers of the third group received Injection Receptal (Intervet International B.V.-Boxmeer, Holland) $2 \mathrm{ml}$ intramuscularly at the time of breeding. After removal of the implant on day 9, all the heifers were subjected to detection of estrus by parading the bull of good sexual drive.

Examination of animals post-treatment and analysis of data: Percentage of heifers exhibiting estrus, time interval between implant removal and onset of estrus and duration of estrus for each heifer were recorded (Table 1). The first acceptance of male by the female was considered as the onset of estrus and non-acceptance of male by the female was considered as cessation of estrus. The duration of estrus was recorded from onset of estrus to cessation of estrus. Heifers identified in estrus were bred by artificial insemination with good quality semen. All the heifers were closely observed for re-occurrence of estrus. The heifers which failed to return in estrus following breeding were examined per rectally on 60th day post breeding for confirmation of pregnancy. Percentages of heifers conceived at induced estrus were considered as first service conception rate. The heifers failed to conceive at the induced estrus and returned to estrus were rebred at subsequent (2nd or 3rd) estrus. Heifers conceived at 2 nd and $3 \mathrm{rd}$ estrus following induced estrus plus heifers conceived at induced estrus were considered as overall conception rate (Table 2). The data collected were suitably tabulated and analyzed following standard statistical method shown by Steel and Torrie [23]. The tests of significance between the treatment groups for onset of estrus after withdrawal of implant and duration of estrus were made by simple completely randomized block design and Duncan's new multiple range test. The Duncan's new multiple 
Estrus induction and fertility response in delayed pubertal Kankrej heifers treated with norgestomet ear implant

\begin{tabular}{lccc}
\hline \multicolumn{4}{l}{ Table - 2. Conception rate in different groups of Kankrej heifers treated with Crestar ear implant } \\
\hline No. of Services & Group $\mathbf{1}(\mathbf{n}=\mathbf{6})$ & Group $\mathbf{2}(\mathbf{n}=\mathbf{6})$ & Group $\mathbf{3}(\mathbf{n}=\mathbf{6})$ \\
\hline First service & $0 / 6(0.0)$ & $2 / 6(33.33)$ & $0 / 6(0.0)$ \\
Second service & $1 / 5(20.0)$ & $2 / 4(50.0)$ & $3 / 5(60.0)$ \\
Third Service & $0 / 2(0.0)$ & $0 / 1(0.0)$ \\
Overall Conception & $1 / 4(25.0)$ & $4 / 6(66.67)$ & $3 / 6(50.0)$ \\
\hline
\end{tabular}

Figures in parenthesis indicate percentage.

range test was performed at 5 percent level of significance.

\section{Results and Discussion}

Induction of estrus: 100 percent (18/18) heifers of all the three groups in the present study responded to the treatment and found in estrus following removal of Crestar ear implant (Table-1). The estrus can be successfully induced in delayed pubertal anoestrus Kankrej heifers with the use of Crestar ear implant alone or in combination with PMSG. The findings obtained by Balasubramanian and Quayam[24], Luthra et al. [25], Sarmah et al. [26], Markendeya and Bharkad[27] and Luthra et al. [28] were in agreement with the present study. However, MacMillan et al. [29] observed only 64 percent Friesian heifers in estrus. Norgestomet implant inhibits the secretion of FSH / LH by the pituitary. Following removal of implant resumption of follicular development and maturation might be due to flux of the Gonadotropin from the pituitary. However, Cavalieri and Fitzpatrick[30] opined that the effectiveness of norgestomet for inducing behavioral estrus in cows is due to the combined effect of progestogen priming on the brain and the direct effect of both exogenously administered estradiol and the high endogenous estradiol on the hypothalamus. The use of PMSG along with Crestar may be useful as PMSG is known to increase blood estrogen and in turn leads to induction of behavioral estrus [12].

Onset of estrus after withdrawal of implant: The interval of onset of estrus following the removal of Crestar ear implant was non - significantly longer in group 1 (25.41 \pm 0.94 hours) then group 2 (21.95 \pm 0.20 hours) and group 3 (22.68 \pm 1.46 hours) (Table 1$)$. The interval of the induction of estrus from the day of removal of implant did not differ with the inclusions of PMSG. The mean interval between Crestar implant withdrawal and onset of induced estrus reported in group 1 was in agreement with King et al. [31]. Where as, Rentfrow et al. [32] and Pinheiro et al. [33] reported comparatively longer estrus induction interval than the present study after withdrawal of implant. The mean interval reported in group 2 and group 3 was in agreement with Luthra et al. [25] and Sarmah et al. [26]. However, Rao et al. [34] and Singh et al. [1] reported comparatively higher interval for onset of estrus following norgestomet plus PMSG treatment.

Duration of estrus: In the present study, significant $(\mathrm{P}<0.05)$ difference in duration of estrus was observed between group $2(25.61 \pm 2.95$ hours $)$ and group 3 (13.48 \pm 1.92 hours). Whereas, group 1 (18.88 \pm 1.45 hours) did not differ significantly from any of the group (Table 1). The duration of induced estrus was significantly longer when PMSG was injected on the day of removal of implant. However, the duration of estrus was at par when Crestar alone or Crestar plus PMSG plus GnRH were used. The mean duration of estrus reported in group 1 was in agreement with Agarwal et al. [35]. While, Tregaskes et al. [36] and Pinheiro et al. [33] recorded comparatively shorter duration of estrus. The mean duration of estrus recorded in group 2 was comparatively shorter than those reported by Sarmah et al. [26] in animals treated with norgestomet plus PMSG, and, it was longer than those noticed by Singh et al. [1] and Nath et al. [37]. The observed differences among the various workers may be due to the method adopted by them for the calculation of duration of estrus.

Fertility Response: 33.33 percent (2/6) first service conception rate was obtained in group 2. However, none of the heifers found pregnant at first service in group 1 and group 3 . The reduced fertility at norgestomet induced estrus may be owing to the luteal dysfunction [31], which may be due to insufficient LH production following implant withdrawal [38]. The pregnancy rate in heifers at induced estrus was quit low in present investigation. But the injection of PMSG may help to improve the conception rate. Similarly, Luthra et al. [28] obtained better conception rate in group of non-cyclic post-pubertal Sahiwal heifers treated with CIDR along with PMSG at the time of CIDR withdrawal in comparison to the group of heifers treated with CIDR alone. The first service conception rate in group 1 and 3 of the present study was in agreement with Hixon et al. [38]. They also 
reported zero percent first service conception rate in anoestrus heifers following induced estrus with Syncro-Mate-B. Khurana [39] reported a single pregnancy out of 105 poor conditioned cows with the same treatment. Selvaraju and Rajasundaram[40] obtained 12.5 percent conception rate in anoestrus cows after norgestomet alone treatment. While, better conception rate was obtained by Rentfrow et al. [32] in Syncro-Mate-B treated Brahman heifers (18.2 percent), Singh et al. [41] in anoestrus heifers and cows (40 percent). The first service conception rate obtained in group 2 was better than those reported by Sarmah et al. [26]. They reported zero percent conception rate at induced estrus with Crestar plus PMSG in prepubertal indigenous heifers. Similarly, low first service conception rate (25 percent) was reported by Rao et al. [34] after norgestomet plus PMSG treatment. Dodamani et al. [42] also gained no extra beneficial effect of PMSG either on estrus response or conception rate in buffaloes.

The overall conception rate obtained in group 1 and group 3 was better than those reported by Selvaraju and Rajasundaram [40]. They obtained 25 percent conception rate in norgestomet treated anoestrus cows. Again, Selvaraju and Rajasundaram [21] achieved 25 percent conception rate with Crestar alone and 50 percent conception rate with Crestar plus $\mathrm{GnRH}$ treatment. The result of the present study in group 2 was in close agreement with Singh et al. [1] and Selvaraju and Rajasundaram [40]. They reported 73.7 percent and 62.5 percent overall conception rate after norgestomet plus PMSG treatment, respectively. However, conception rate of group 2 was lower than those obtained by Luthra et al. [25]. They obtained 86 percent overall conception rate after norgestomet plus PMSG treatment.

\section{Conclusion}

Although the conception rate at induced estrus was lower, norgestomet ear implant could be utilized to induced estrus in delayed pubertal cow heifers. Compared to norgestomet alone, good fertility response could be achieved when PMSG was injected at norgestomet implant removal.

\section{Authors' Contribution}

CF Chaudhari, BN Suthar, VK Sharma, VS Dabas and $\mathrm{HH}$ Panchasara implemented the study design and carried out the experiment. CF Chaudhari, BN Suthar, VK Sharma, VS Dabas analysed the data. CF Chaudhari, BN Suthar, VK Sharma, VS Dabas, HH Panchasara and NF Chaudhari drafted and revised the manuscript. All authors read and approved the final manuscript.

\section{Acknowledgements}

The authors are highly thankful to the staff of Livestock Research Station and Department of Animal Reproduction, Gynaecology and Obstetrics; College of Veterinary Science and Animal Husbandry, Sardarkrushinagar Dantiwada Agricultural University, Sardarkrushinagar for providing necessary help for the study.

\section{Competing interests}

Authors declare that they have no Competing interests.

\section{References}

1. Singh, U., Khurana, N. K. and Inderjeet. (1998). Plasma progesterone profiles and fertility status of anoestrus zebu cattle treated with norgestometestradiol-eCG regimen. Theriogenology 50: 11911199.

2. Britt, J. H. (1987). Induction and synchronization of ovulation. In: Reproduction in Farm Animals. 5th edn. Pp. 507- 515. (Ed.) Hafez, E.S.E. Lea and Febiger, Philadelphia.

3. Markandeya, N. M., Dhoble, R. L., Bhikane, A. U. and Bharkad, G. P. (2002). Ten years clinical trial experience with Prajana: Overview of its efficacy in true anestrus cases. Livestock International 10: 11-13.

4. Markandeya, N. M., Bharkad, G. P. and Bhikane, A. U. (2004). Clinical response to herbal therapy in selected anestrus cases. Veterinary Practitioner 5: 2930.

5. Mohanty, L. D., Mishra, B. and Mishra, P. C. (2007). Follow up of sexual health of anestrus animals by use of estrus inducers, Prajana 'HS' in a Holstein Friesian dairy herd. Livestock International 11: 12-13.

6. Biswas, J., Ray, S. K., Giri, S. C. and Mitra, J. (2008). Clinical efficacy of injectable herbal heat inducer in anoestrus Murrah buffaloes. The Indian Journal of Animal Reproduction 29 (2): 202-205.

7. Patil, A. D., Markandeya, N. M. and Bhikane, A. U. (2009). Efficacy of herbal drug in inducing estrus in delayed pubertal Deoni heifers. Indian Journal of Animal Reproduction 30 (2): 10-12.

8. Patra, M. K., Kumar, H., Yadav, M. C., Meur, S. K., Varshney, V. P., Mahmood, S. and Tomar, A. K. S. (2006). Biostimulation: A tool for induction of estrus in prepubertal crossbred heifers. XXII Annual convention and national symposium on Innovative Technologies for Fertility Enhancement in Livestock. 10th-12th November. Mhow. pp 117-118.

9. Ahmad, S., Kumar, H., Yadav, M. C., Singh, J., Singh, G. and Patra, M. K. (2010). Biostimulatory effects of bull urine on ovarian activity and reproductive performance in post-partum crossbred cows. Indian 
Estrus induction and fertility response in delayed pubertal Kankrej heifers treated with norgestomet ear implant

Journal of Animal Sciences 80 (6): 519-522.

10. Dutta, S., Dey, R. A. and Misra, R. K. (2001). Health constraints of crossbred cattle in rural Bengal. Indian Dairyman 53: 53-56.

11. Mathur, A. K., Srivastava, S., Tyagi, S. and Mandal, D. K. (2005). Effect of vitamin A and mineral administration on the induction of oestrus in anoestrus Frieswal and Sahiwal heifers. The Indian Journal of Animal Reproduction 26 (1): 60-61.

12. Singh, A., Saxena, M. S. and Prasad, Shiv. (2004). Efficacy of Crestar and its combination with Folligon on post-partum anoestrus in buffalo. The Indian Journal of Animal Reproduction 25: 43 - 44.

13. Sirmour, S., Nema, S. P., Singh, B. K. and Sukla, S. P. (2006). Induction of oestrus in delayed pubertal cross-bred heifers. The Indian Journal of Animal Reproduction 27 (1): 55-58.

14. Mavi, P. S., Bahga, C. S., Singh, Narinder and Cheema, R. (2007). Effect of hormonal treatment on induction of estrus and plasma mineral composition in true anestrus buffalo heifers. The Indian Journal of Animal Reproduction 28 (1): 39-41.

15. Utage, S. G., Raghuwanshi, D. S., Vhora, S. C., Khan, L. A., Sirsat, P. R. and Gawande, A. P. (2007). Efficacy of Crestar and PGF2á combination in treatment of post partum anestrus buffaloes. The Indian Journal of Field Veterinarians 2 (4): 19-21.

16. Singh, Ram Shyam., Saxena, A., Ghuman, S. P. S., Kumar, B., Singh, S., Verma, A. K. and Hussain. A. (2010). Effect of progesterone impregnated intravaginal sponges on induction of estrus and conception rate in buffaloes. XXVI Annual convention and International symposium on Biotechnologies for Optimization of Reproductive Efficiency of Farm and Companion Animals to Improve Global Food Security and Human Health. 10th - 12th November. G.B.P.U.A.\&T., Pantnagar. pp 47-48.

17. Peters, A. R. and Laming, G. E. (1986). Regulation of ovarian function in the postpartum cow: An endocrine model. Veterinary Record 118: 236-239.

18. Murugavel, K., Antoine, D. and Raju, M. S. (2010). Comparison of norgestomet ear implant and CIDR treatment on fertility in anestrus cows. Indian Veterinary Journal 87: 763-765.

19. Nath, N. Ch., Sarmah, B. C., Deka, B. C. and Baruah, K. K. (2011). Hormonal changes in anestrous cattle following treatment for improvement of reproductive efficiency. Indian Veterinary Journal 88: 38-40.

20. Nayak Vivek, Agrawal, R. G., Thakur, M. S., Shrivastava, O. P. and Jain Aklank. (2006). Efficacy of Crestar implant alone and in combination with Folligon for estrus induction in true anoestrus buffaloes. XXII Annual convention and national symposium on Innovative Technologies for Fertility Enhancement in Livestock. 10th - 12th November. Mhow. pp 312A-313.

21. Selvaraju, S. and Rajasundaram, R. C. (2001). Effect of $\mathrm{GnRH}$ on fertility response in norgestomet primed postpartum anoestrous cows. Indian Vet. Journal 78 : 325-326.

22. Schmitt, EJ-P., Diaz, T., Barros, C. M., de la Sota, R. L., Drost, M. and Fredriksson, E. W. (1996). Differential responses of luteal phase and fertility in cattle following ovulation of the first wave follicle with human chorionic gonadotrophin or an agonist of gonadotrophin releasing hormone. Journal of Animal Science 74: 1074-83.

23. Steel, R. G. D. and Torrie, J. H. (1981). Principles and Procedures of Statistics, A Biometric Approach. 2nd Edn. Mc Graw Hill, Int. Book Agency, Singapore.

24. Balasubramanian, S. and Quayam, S. A. (1992). Oestrus synchronization and pregnancies in crossbred heifers treated with Syncro-Mate- B. Indian Veterinary Journal 69: 38-40.

25. Luthra, R. A., Khar, S. K. and Singh, K. P. (1994). Oestrus induction and synchronization in cows and buffaloes with synthetic progestagens. Indian Journal of Animal Science 64 (10): 1060-1061.

26. Sarmah, B. K., Dutta, D. J., Sharmah, B. C. and Deka, B. C. (2003). Effect of mating on reproductive performances in hormonally induced pubertal heifers. Indian Journal of Animal Science 73 (11):1211-1213.

27. Markendeya, N. M. and Bharkad, G. P. (2004). Controlled breeding with norgestomet ear implant for induction of post partum oestrus in Deoni cows. The Indian Journal of Animal Reproduction 25 (1): 53-54.

28. Luthra, R. A., Munjal, V. K. and Nanda, T. (2007). Reproductive performance of non-cyclic postpubertal Sahiwal heifers treated with natural progestogens. XXIII Annual convention and national symposium on Challenges in Improving Reproductive Efficiency of Farm and Pet Animals. 7th - 9th December. Bhubaneswar. pp 42.

29. MacMillan, K. L., Taufa, V. K. and Morris, G. R. (1996). Patterns of oestrus vary with different form of synchrony. Proceeding of the New Zealand Society of Animal Production 56: 347-349.

30. Cavalieri, J. and Fitzpatrick, L. A. (1995). Oestrus detection techniques and insemination strategies in Bos indicus heifers synchronized with norgestometestradiol. Australian Veterinary Journal 72(5): 177182.

31. King, M. E., Odde, K. G., LeFever, D. G., Brown, L. N. and Neubauer, C. J. (1986). Synchronization of estrus in embryo transfer recipients receiving demiembryos with Syncro-mate-B op estrumate. Theriogenology 26(2): 221-229.

32. Rentfrow, L. R., Randel, R. D. and Neuendoeff, D. A. (1987). Effect of estrus synchronization with Syncromate-B ${ }^{\circledR}$ on serum luteinizing hormone, progesterone and conception rate in Brahman heifers. Theriogenology 28(3): 355-358.

33. Pinheiro, O. L., Barros, C. M., Figueiredo, R. A., Do Valle, E. R., Encarnacao, R. O. and Padovani, C. R. 
(1998). Estrous behavior and the estrus-toovulation interval in Nelore cattle (Bos indicus) with natural estrus or estrus induced with prostaglandin F2 or norgestomet and estradiol valerate. Theriogenology 49: $667-681$

34. Rao, A. V. N., Rao, A. N. and Venkatramaiah, P. (1986). Induced puberty in prepureral zebu heifers treated with norgestoment and pregnant mare serum Gonadotropin. Theriogenology 26(1): 27-36.

35. Agarwal, S. K., Shankar, U., Kumar, S. and Mohan, G. (2001). Ovarian cyclicity and progesterone profile in postpartum anoestrus cattle using a synthetic progestogen, norgestomet regime. Indian Journal of Animal Science 71: 1120-1123.

36. Tregaskes, L. D., Broadbent, P. J., Dolman, D. F., Grimmer, S. P. and Franklin, M. F. (1994). Evaluation of Crestar, a synthetic progestogen regime, for synchronizing oestrus in maiden heifers used as recipients of embryo transfers. The Veterinary Record 92-94.

37. Nath, H. C., Dutta, D., Dutta, A. and Biswas, R. K. (2004). Effect of Crestar administration on oestrus response in postpartum anoestrous cows. Indian
Journal of Animal Sciences 74 (1):22-24.

38. Hixon, D. L., Kesler, D. J., Troxel, T. R., Vincent, D. L. and Wiseman, B. S. (1981). Reproductive hormone secretions and first service conception rate subsequent to ovulation control with Synchro-mate B. Theriogenology 16(2): 219-229.

39. Khurana, N. K. (1999). Use of norgestomet ear implants for induction of estrus in acyclic indigenous cows: Effect of body condition. XVth ISSAR Convention Compendium, pp 24.

40. Selvaraju, S. and Rajasundaram, R. C. (1999). Effect of eCG on fertility in norgestomet primed postpartum anoestrus cows. Indian J. Anim. Reproduction 20: 91-93.

41. Singh, M., Vasishta, N. K., Sood, P. and Sharma, A. (2001). Evaluation of norgestomet, a synthetic progestogen for inducing oestrus and subsequent fertility in heifers and postpartum anoestrus cows. Indian Veterinary Journal 78: 961-962.

42. Dodamani, M. S., Tandle, M. K., Mohteshamuddin, K. and Honnappagol, S. S. (2011). Induction of Fertile estrus in true anoestrus by re-utilization of Crestar implants in She buffaloes. Veterinary world 4(1): 28-30. 